\title{
Statistical Analysis on Impact Toughness of Welded Joints between B610CF and 16MnR Steel
}

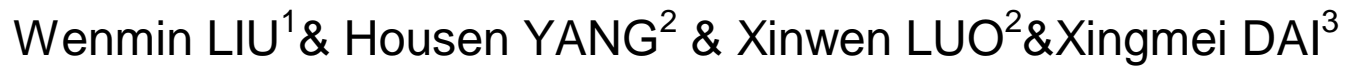 \\ ${ }^{1}$ Yunnan Agricultural University, College of Water Conservancy, Kunming, China \\ ${ }^{2}$ Yunnan Agricultural University, College of Mechanical and Electrical Engineering, Kunming, Chi- \\ na \\ ${ }^{3}$ Yunnan Agricultural University, College of Water Conservancy, Kunming, China
}

\begin{abstract}
KEYWORD: B610CF steel; 16MnR steel; Welded joint; Impact toughness
ABSTRACT: It was investigated for statistical analysis on impact toughness of welded joints between B610CF and 16MnR steel using shielded metal arc welding (SMAW) and mixed gas arc welding $(\mathrm{MGAW})$ method. Low temperature $\left(-20^{\circ} \mathrm{C}\right)$ impact toughness experiments and normal temperature $\left(20^{\circ} \mathrm{C}\right)$ impact toughness experiments after $5 \%$ strain age were carried out on weld metal (WM) and heat affected zone (HAZ) of the welded joints. F testing, $t$ and $t^{\prime}$ testing statistical methods were used to analyze the difference of welded joint impact toughness between the two welding methods. The statistical analysis shows that the disperstiveness of impact toughness $\left(-20^{\circ} \mathrm{C}\right)$ in WM using SMAW is significantly smaller than the one using MGAW, but the mean value has no significant difference. And there are no significantly statistical difference for the disperstiveness and mean value of $-20^{\circ} \mathrm{C}$ impact toughness in $\mathrm{HAZ}$, and normal temperature impact toughness after $5 \%$ strain age in $\mathrm{WM}$ and HAZ between the two welding methods.
\end{abstract}

\section{Introduction}

B610CF steel is a low carbon bainitic steel with high strength and good toughness at low temperatures $^{[1]}$, and low weld cracking; $16 \mathrm{MnR}$ steel is also used in water conservancy and hydropower project more than a broad one kinds of low alloy high strength steel. In the pipeline water pressure in water conservancy and Hydropower Engineering, the upstream pressure smaller parts made of $16 \mathrm{MnR}$ steel strength small,B610CF steel in the downstream pressure with high level of strength, welding between dissimilar steel joints of different intensity levels before the two kinds of steels. SMAW and GMAW welding structures are often used in construction, for both welding methods on the study of the performance of welded joints, mainly based on the experimental data to visually determine the impact of welding on joint performance ${ }^{[2]}$, but not from a statistical point of research on effects of welding methods on the properties of welded joint.

In this paper, using shielded metal arc welding (referred to as SMAW) and mixed gas arc welding (referred to as SMAW MGAW ) two welding methods in different welding conditions on B610CF and $16 \mathrm{MnR}$ welding joint of dissimilar steel plate butt welding, after low temperature impact toughness test and after 5\% after strain aging impact and low temperature $\left(-20^{\circ} \mathrm{C}\right)$ impact toughness experiments and normal temperature $\left(20^{\circ} \mathrm{C}\right)$ impact toughness experiments after $5 \%$ strain age were carried out on weld meta (WM) and heat affected zone (HAZ) of the welded joints. F testing, $t$ and $t^{\prime}$ testing statistical methods were used to analyze the difference of welded joint impact toughness between the two welding methods.

\section{Test Materials and Welding}

\section{Test Materials}

Test base metal B610CF and 16MnR plate (thickness $\delta=36 \mathrm{~mm}$ ), when using manual welding, the welding materials for CHE507 electrode; With gas shielded arc welding, welding material for CHW$50 \mathrm{C} 6$ welding wire, protective gas is $80 \% \mathrm{Ar}+20 \% \mathrm{CO} 2$. To retest the base metal and chemical composition and mechanical properties of welding materials retest, results are shown in Table 1 and table 2., base metal microstructure shown in Figure 1, figure 1 in base material of metallographic structure of 
B610CF steel in ferrite grain growth in a typical lath bainite black needle flake shape, and dispersed fine carbides; $16 \mathrm{MnR}$ matrix as banded iron has obvious characteristics of ferrite and pearlite.

Table 1. Chemical composition of experiment material (\%)

\begin{tabular}{cccccccccccccc}
\hline \multirow{2}{*}{ Name } & \multirow{2}{*}{$\mathrm{C}$} & $\mathrm{S}$ & $\mathrm{N}$ & $\mathrm{S}$ & $\mathrm{P}$ & $\mathrm{C}$ & $\mathrm{Ni}$ & $\mathrm{C}$ & $\mathrm{M}$ & $\mathrm{V}$ & $\mathrm{N}$ & $\mathrm{B}$ \\
& & $\mathrm{i}$ & $\mathrm{n}$ & & & $\mathrm{u}$ & & $\mathrm{r}$ & $\mathrm{o}$ & & $\mathrm{b}$ & \\
\hline B610CF & 0.08 & 0.24 & 1.4 & 0.002 & 0.01 & 0.02 & 0.17 & 0.14 & 0.21 & 0.04 & 0.02 & 0.0004 \\
16MnR & 0.15 & 0.32 & 1.51 & 0.001 & 0.015 & 0.14 & 0.12 & 0.03 & $/$ & $/$ & 0.028 & $/$ \\
CHE507 & 0.08 & 0.54 & 1.05 & 0.01 & 0.01 & $/$ & 0.02 & 0.05 & 0.03 & 0.01 & $/$ & $/$ \\
CHW-50C6 & 0.08 & 0.92 & 1.52 & 0.015 & 0.02 & 0.2 & $/$ & $/$ & $/$ & $/$ & $/$ & $/$ \\
\hline
\end{tabular}

Table 2. Mechanical property of experiment material

\begin{tabular}{ccccc}
\hline Name & $\mathrm{R}_{\mathrm{eL}}(\mathrm{MPa})$ & $\mathrm{R}_{\mathrm{m}}(\mathrm{MPa})$ & $\mathrm{A}(\%)$ & $-20^{\circ} \mathrm{C} \mathrm{A}_{\mathrm{KV}}(\mathrm{J})$ \\
\hline $\mathrm{B} 610 \mathrm{CF}$ & 655 & 705 & 19 & $281,276,273$ \\
$16 \mathrm{MnR}$ & 363 & 537 & 30 & $238,246,252$ \\
CHE507 & 430 & 540 & 30 & $102,123,145$ \\
CHW-50C6 & 440 & 555 & 29 & $90,103,85$ \\
\hline
\end{tabular}

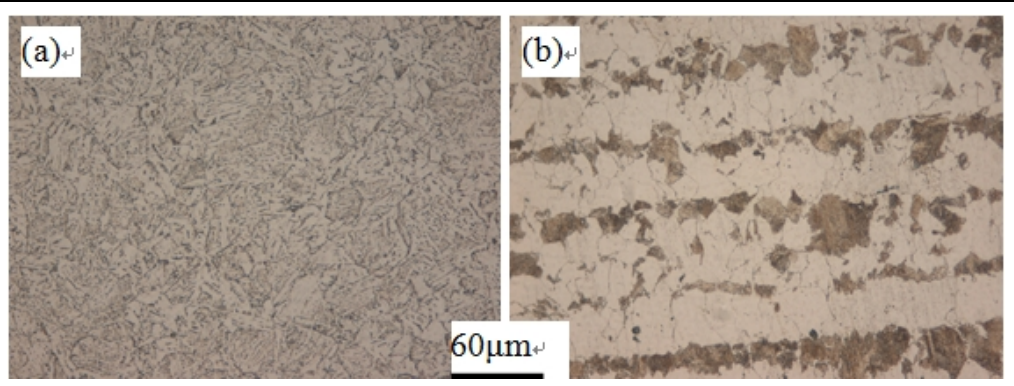

Figure 1. Metallurgical microstructure (a) B610CF steel(b) 16MnR steel

\section{Welding parameters}

When using manual arc welding, plate-shaped groove in the form of a butt joint is an asymmetric Xtype, when using gas shielded arc welding, the groove in the form of a plate butt joints symmetrical $\mathrm{X}$ type. CHE507 welding wire before baking to 380 to 400 degrees and holding 1 hour. Both welding methods use multi-pass welding, carbon arc gouging, grinding wheel; preheat $80 \sim 120{ }^{\circ} \mathrm{C}$, the temperature control interlayer between preheating temperature and $200{ }^{\circ} \mathrm{C}$; eliminate hydrogen heat treatment after welding temperature is $150 \sim 200{ }^{\circ} \mathrm{C}$, heat 1 hour. The two kinds of welding methods were selected third gear changes welding heat input welding, weld heat input is mainly by changing the welding speed, welding position, swinging ways, the welding parameters are shown in Table 3.

Table 3. Welding parameter of B610CF and $16 \mathrm{MnR}$ steel

\begin{tabular}{ccccccc}
\hline $\begin{array}{c}\text { Welding } \\
\text { method }\end{array}$ & $\begin{array}{c}\text { Welding } \\
\text { test plate } \\
\text { number }\end{array}$ & $\begin{array}{c}\text { Electrode di- } \\
\text { ameter(mm) }\end{array}$ & $\begin{array}{c}\text { Welding } \\
\text { current(A) }\end{array}$ & $\begin{array}{c}\text { Arc vol- } \\
\text { tage(V) }\end{array}$ & $\begin{array}{c}\text { Welding } \\
\text { speed(cm/m } \\
\text { in) }\end{array}$ & $\begin{array}{c}\text { Average } \\
\text { welding heat } \\
\text { input (kJ/cm) }\end{array}$ \\
\hline Manual & Y-1 & $3.2 / 4.0$ & $125-185$ & $22-25$ & $9.2-12.5$ & 23 \\
welding & Y-2 & $3.2 / 4.0$ & $125-185$ & $22-25$ & $9.2-12.5$ & 24.5 \\
& Y-3 & $3.2 / 4.0$ & $125-165$ & $22-25$ & $5.5-7.8$ & 37 \\
\hline Gas & Z-1 & 1.2 & $120-160$ & $22-23$ & $9.2-12.5$ & 20 \\
shielded & Z-2 & 1.2 & $120-160$ & $22-23$ & $7-12$ & 22 \\
welding & Z-3 & 1.2 & $120-165$ & $22-23$ & $6.5-10$ & 29 \\
\hline
\end{tabular}




\section{The impact toughness test of welded joints}

Each welding specifications of welded plates after welding, respectively in the weld center and heat affected zone of the multiple impact toughness of samples, 20 degrees low temperature impact toughness test and after 5\% strain age at room temperature of 20 degrees impact toughness test, the sample for the Charpy V-type, the test results shown in Table 4. 5\% strain aging impact performance test, the sample is first carried out in a 5\% after tensile deformation is heated to 250 degrees and holds for 1 hour, then cooled to room temperature, room temperature $20{ }^{\circ} \mathrm{C}$ impact toughness test.

Table 4 Mechanical property of B610CF and 16MnR steel welded joints

\begin{tabular}{|c|c|c|c|c|}
\hline Welding & & $-20^{\circ} \mathrm{C} \mathrm{A}_{\mathrm{KV}} / \mathrm{J}$ & & $\operatorname{train} 20^{\circ} \mathrm{C} A_{V S} / \mathrm{J}$ \\
\hline test plate & Weld line & Heat affected zone & Weld line & Heat affected zone \\
\hline Y-1 & $132 ; 110 ; 125$ & $\begin{array}{l}\text { 16MnR side:162;186;134 } \\
\text { B610CF side:294;297;288 }\end{array}$ & $163 ; 176 ; 176$ & $\begin{array}{l}\text { 16MnR side:216;195;207 } \\
\text { B610CF side:222;237;200 }\end{array}$ \\
\hline Y-2 & $118 ; 118 ; 122$ & $\begin{array}{l}\text { 16MnR side:190;172;222 } \\
\text { B610CF side:162;231;295 }\end{array}$ & $144 ; 143 ; 138$ & $\begin{array}{l}\text { 16MnR side: } 162 ; 276 ; 172 \\
\text { B610CF side: } 174 ; 254 ; 286\end{array}$ \\
\hline Y-3 & $78 ; 68 ; 84$ & $\begin{array}{l}\text { 16MnR side: } 236 ; 100 ; 196 \\
\text { B610CF side: } 196 ; 270 ; 184\end{array}$ & $80 ; 86 ; 76$ & $\begin{array}{l}\text { 16MnR side:230;233;240 } \\
\text { B610CF side: } 232 ; 254 ; 240\end{array}$ \\
\hline Z-1 & $166 ; 142 ; 114$ & $\begin{array}{l}\text { 16MnR side: } 160 ; 160 ; 180 \\
\text { B610CF side: } 293 ; 218 ; 228\end{array}$ & $172 ; 172 ; 107$ & $\begin{array}{l}\text { 16MnR side: } 180 ; 172 ; 186 \\
\text { B610CF side: } 266 ; 274 ; 210\end{array}$ \\
\hline Z-2 & $46 ; 58$ & $\begin{array}{l}\text { 16MnR side: } 172 ; 252 ; 142 \\
\text { B610CF side: } 224 ; 155 ; 292\end{array}$ & $132 ; 111 ; 106$ & $\begin{array}{l}\text { 16MnR side: } 247 ; 256 ; 285 \\
\text { B610CF side: } 196 ; 284 ; 285\end{array}$ \\
\hline Z-3 & $58 ; 46 ; 56$ & $\begin{array}{l}\text { 16MnR side: } 172 ; 210 ; 216 \\
\text { B610CF side: } 293 ; 297 ; 295\end{array}$ & $106 ; 72 ; 82$ & $\begin{array}{l}\text { 16MnR side: } 230 ; 174 ; 233 \\
\text { B610CF side: } 290 ; 288 ; 170\end{array}$ \\
\hline
\end{tabular}

\section{Comparative Study Impact toughness}

The actual welding process, due to the limitation of welded structures construction positions may need to be welded in various welding positions, generally vertical position welding heat input is large, horizontal welding position of the welding heat input is small, the actual welding structure of the various heat input may exist. Therefore, Table 4 SMAW and MGAW welding specifications in a variety of weld metal and heat affected zone toughness, respectively, as a sample, using the F testing and t testing from a statistical point of view of both welding methods impact toughness of welded joints weld zone and heat affected zone.

For B610CF and 16MnR dissimilar weld joints in both welding methods weld zone and heat affected zone toughness normal distribution fit test studies, impact toughness values are normally distributed. By F testing ${ }^{[3]}$ The standard deviation impact toughness and weld the two manual welding and gas welding method under inspection to determine whether the standard deviation between the two have significant differences; and the use of $t$ and $t$ 'testing for the average impact toughness and weld the two manual welding gas welding method under inspection, to determine whether there is a significant difference between the mean.

\section{Principle of the Test}

Using the $\mathrm{F}$ testing for the impact of both welding methods toughness comparative analysis of variance $^{[3]}$, assuming that:

$$
\left.\begin{array}{l}
H_{0}: \boldsymbol{\sigma}_{1}^{2}=\sigma_{2}^{2} \\
H_{1}: \boldsymbol{\sigma}_{1}^{2}>\boldsymbol{\sigma}_{2}^{2} \text { Or } \boldsymbol{\sigma}_{1}^{2}<\boldsymbol{\sigma}_{2}^{2}
\end{array}\right\}
$$

Type (1) for the value of the variance of overall joint impact toughness of welding two welding methods, when established, have 


$$
F=\frac{\left(n_{2}-1\right) n_{1} s_{1}^{2}}{\left(n_{1}-1\right) n_{2} s_{2}^{2}} \sim F_{\alpha}\left(n_{1}-1, n_{2}-1\right)
$$

Type (1) for the two kinds of welding methods welding joint impact toughness value of the sample variance, the number of samples for sample. The larger variance as a numerator and the smaller as the denominator to calculate the F testing statistic. At a given confidence level, check the F-test distribution table to get a critical value. The F value calculation compared with the critical value, if:, is rejected, that the two sub-sample variance there is a significant difference; otherwise accepted ,think, it that there was no significant difference in variance.

If there is no significant difference between the variance test, $t$ testing was used for two of the population mean, hypothesis:

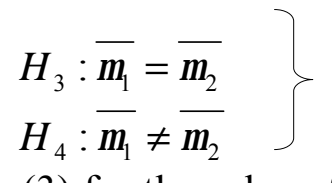

Type (3) for the value of the overall mean impact toughness of welded joint of two kinds of welding methods. When established, there are:

$$
t=\sqrt{\frac{n_{1} n_{2}\left(n_{1}+n_{2}-2\right)}{n_{1}+n_{2}}} \frac{\left(\overline{x_{1}}-\overline{x_{2}}\right)}{\sqrt{\left(n_{1}-1\right) s_{1}^{2}+\left(n_{2}-1\right) s_{2}^{2}}} \sim t_{\alpha}\left(n_{1}+n_{2}-2\right)
$$

Type (4) in two kinds of welding methods under the impact toughness of welding joint of the sample mean value. According to equation (4) statistical calculation of the two sample $t$ testing value, check the distribution table,you can get the critical value of confidence level, the statistical values were compared with the critical value, if || is less than the critical value, it is accepted that two overall, between the impact toughness of the mean no significant difference. If greater than the critical value, refused to , that means the impact toughness between two overall have significant difference, and greater than ; if less than - , is rejected, that the mean impact toughness between two overall have significant difference, and less than .

If there are significant differences in variance, $t$ testing[4] is used approximation namely $t$ 'testing for two population means test, the test statistic according to formula (5) is calculated, the critical value according to formula (6) calculation, test with the $t$ testing.

$$
\begin{aligned}
& t^{\prime}=\frac{\left(\overline{x_{1}}-\overline{x_{2}}\right)}{\sqrt{s_{1}^{2} / n_{1}+s_{2}^{2} / n_{2}}} \sim t_{\alpha}\left(n_{1}+n_{2}-2\right) \\
& t_{\alpha}^{\prime}=\frac{\frac{s_{1}^{2}}{n_{1}} \times t_{\alpha}\left(n_{1}-1\right)+\frac{s_{2}^{2}}{n_{2}} \times t_{\alpha}\left(n_{2}-1\right)}{s_{1}^{2} / n_{1}+s_{2}^{2} / n_{2}} \ldots \ldots
\end{aligned}
$$

\section{Principle of the Test}

The mean and standard toughness value difference calculated according to the following Table 4, two welding the weld zone and heat affected zone impact at $-20{ }^{\circ} \mathrm{C}$ low temperature, as shown in Table 5, in which the gas weld toughness number of samples are 8 , and the remaining number of samples are 9. Test statistic and critical values are shown in Table 5, where the significance level is. Table 5 welds variance have significant differences, using t 'testing to test the mean, the rest were performed using the $\mathrm{t}$ testing mean testing.

According to table 4 computes the mean and standard of two kinds of welding methods of weld zone and heat affected zone after 5\% strain age impact toughness at 20 degrees, see Table 6 (the number of samples are 9). F testing and t testing results are shown in Table 6. 
Table 5 Statistical results of impact toughness $\left(-20^{\circ} \mathrm{CA} \mathrm{KV}\right)$

\begin{tabular}{|c|c|c|c|c|c|c|c|}
\hline \multicolumn{2}{|r|}{ Welding method } & $\frac{\text { Mean }}{x}$ & $\begin{array}{l}\text { Standard } \\
\text { deviation }\end{array}$ & $\begin{array}{l}\text { F Inspec- } \\
\text { tion value }\end{array}$ & $\begin{array}{c}\text { Critical } \\
\text { value }\end{array}$ & $\begin{array}{l}\text { t or t' Inspec- } \\
\text { tion value }\end{array}$ & Critical value \\
\hline \multirow{2}{*}{$\begin{array}{l}\text { Weld } \\
\text { line }\end{array}$} & Manual welding & 106.11 & 23.21 & \multirow{2}{*}{4.31} & \multirow{2}{*}{$\begin{array}{c}F_{0.1}(7,8)=2.6 \\
3\end{array}$} & \multirow{2}{*}{$\mathrm{t}^{\prime}=1.1$} & \multirow{2}{*}{$t_{0.1}^{\prime}=1.412$} \\
\hline & Gas shielded welding & 85.75 & 47.79 & & & & \\
\hline \multirow{4}{*}{ HAZ } & $\begin{array}{c}\text { Manual welding } \\
\text { 16MnR side }\end{array}$ & 177.56 & 42.04 & \multirow{2}{*}{1.48} & \multirow{2}{*}{$F_{0.1}(8,8)=2.59$} & \multirow{2}{*}{$\mathrm{t}=-0.4$} & \multirow{2}{*}{$\begin{array}{c}t_{0.1}(16)=1.33 \\
7\end{array}$} \\
\hline & $\begin{array}{c}\text { Gas shielded welding } \\
16 \mathrm{MnR} \text { side }\end{array}$ & 184.89 & 34.53 & & & & \\
\hline & $\begin{array}{l}\text { Manual welding } \\
\text { B610CF side }\end{array}$ & 246.33 & 53.93 & \multirow{2}{*}{1.13} & \multirow{2}{*}{$F_{0.1}(8,8)=2.59$} & \multirow{2}{*}{$\mathrm{t}=-0.35$} & \multirow{2}{*}{$\begin{array}{c}t_{0.1}(16)=1.33 \\
7\end{array}$} \\
\hline & $\begin{array}{c}\text { Gas shielded welding } \\
\text { B610CF side }\end{array}$ & 255 & 50.84 & & & & \\
\hline
\end{tabular}

Table 6 Statistical results of impact toughness after strain aging $\left(20^{\circ} \mathrm{CA}_{\mathrm{vs}}\right)$

\begin{tabular}{|c|c|c|c|c|c|c|c|}
\hline \multicolumn{2}{|c|}{ Welding method } & $\underset{[J]}{\operatorname{Mean}} \bar{x}$ & $\begin{array}{l}\text { Standard } \\
\text { deviation }\end{array}$ & $\begin{array}{l}\text { F Inspec- } \\
\text { tion value }\end{array}$ & $F_{0.1}(8,8)$ & $\begin{array}{l}t \text { Inspec- } \\
\text { tion value }\end{array}$ & $t_{0.1}(16)$ \\
\hline \multirow{2}{*}{$\begin{array}{l}\text { Weld } \\
\text { line }\end{array}$} & Manual welding & 131.33 & 40.44 & \multirow[b]{2}{*}{1.32} & \multirow[b]{2}{*}{2.59} & \multirow[b]{2}{*}{0.76} & \multirow[b]{2}{*}{1.337} \\
\hline & $\begin{array}{l}\text { Gas shielded } \\
\text { welding }\end{array}$ & 117.78 & 35.17 & & & & \\
\hline \multirow{4}{*}{ HAZ } & $\begin{array}{l}\text { Manual welding } \\
16 \mathrm{MnR} \text { side }\end{array}$ & 214.56 & 35.38 & \multirow[b]{2}{*}{1.36} & \multirow[b]{2}{*}{2.59} & \multirow[b]{2}{*}{-0.2} & \multirow[b]{2}{*}{1.337} \\
\hline & $\begin{array}{c}\text { Gas shielded weld- } \\
\text { ing } \\
16 \mathrm{MnR} \text { side }\end{array}$ & 218.11 & 41.33 & & & & \\
\hline & $\begin{array}{l}\text { Manual welding } \\
\text { B610CF side }\end{array}$ & 233.22 & 32.5 & \multirow[b]{2}{*}{2.03} & \multirow[b]{2}{*}{2.59} & \multirow[b]{2}{*}{-0.97} & \multirow[b]{2}{*}{1.337} \\
\hline & $\begin{array}{c}\text { Gas shielded weld- } \\
\text { ing } \\
\text { B610CF side }\end{array}$ & 251.44 & 46.31 & & & & \\
\hline
\end{tabular}

As shown in Table 5, $\mathrm{F}$ testing values of two ways low temperature impact toughness of the weld zone is greater than the critical value, and the variance of large gas shielded arc welding, gas welding seam to explain the low temperature impact toughness dispersion was significantly greater than the manual welding; However, when the test statistic is less than the critical value means tests, indicating that both methods weld zone impact toughness mean significant differences. Regardless $16 \mathrm{MnR}$ side or B610CF side of $\mathrm{F}$ testing value and t testing value of the heat affected zone of low temperature impact toughness are less than the critical value, indicating that both sides welding heat affected zone $-20{ }^{\circ} \mathrm{C}$ low temperature impact toughness dispersion and size are not significant differences.

Be seen from Table $6, \mathrm{~F}$ testing value and t testing values are less than the critical value, indicating whether the variance and the mean weld zone or heat affected zone on both sides after the strain aging room temperature impact toughness are no significant differences between both methods, that is, after a $5 \%$ strain aging were no significant differences in room temperature impact toughness dispersion and size.

\section{Summary}

(1) B610CF and $16 \mathrm{MnR}$ dissimilar steels when using SMAW welding $-20{ }^{\circ} \mathrm{C}$ impact toughness dispersion less than a mixed gas shielded arc welding, but no significant difference in the mean.

(2) No significant effect of these two methods of welding heat affected zone on both sides of $-20{ }^{\circ} \mathrm{C}$ impact toughness dispersion and mean, and the weld metal, B610CF and 16MnR heat affected zone 
on both sides after impact 5\% strain at room temperature after aging toughness dispersion and mean no significant impact.

\section{REFERENCES}

[1] Tianhui ZHANG, Fangwei JIN, Peijun YAN,Etc. B610CF steel welded joint and Performance Analysis[J]. Thermal processing technology, 2010, 39(5):161-163.

[2]Tianhui ZHANG, Housen YANG,Jie SHI,Etc. Effect of welding processes on B610CF and 16MnR dissimilar weld joints[J]. Welding Technology, 2013,42(3):26-29.

[3]Weixin LIU. Mechanical Reliability Design[M].BeiJing: Tsinghua University Press, 1996

[4]Liangwei GONG, Weidong TIAN. Evaluation of Mineral Dust Control Measures Statistical Analysis Method and Its Application[J]. Metal Mines, 2013(8):143-146. 